\title{
Vitrectomy with and without scleral buckling for retinal detachment
}

\author{
Vitrectomia com e sem "scleral buckling" para descolamento da retina
}

\author{
Rubens Camargo Siqueira1 \\ Cássio Villa Marin C. Gomes ${ }^{2}$ \\ Cláudio Dalloul ${ }^{3}$ \\ Rodrigo Jorg' $^{4}$
}

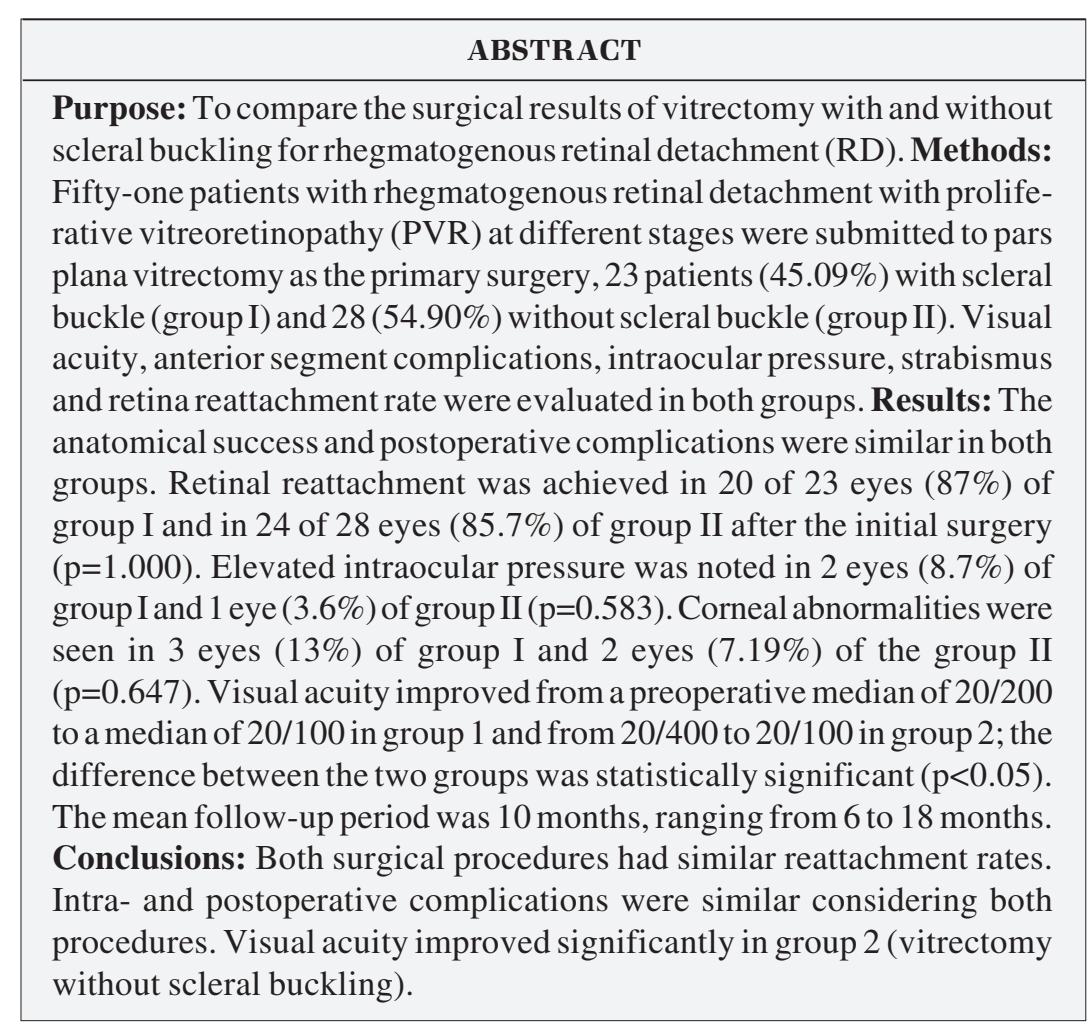

Keywords: Retinal detachment; Scleral buckling; Vitrectomy; Visual acuity; Comparative study

\section{INTRODUCTION}

Pars plana vitrectomy (PPV) combined with a moderately high and broad scleral buckling (SB) is the standard treatment for retinal detachment with proliferative vitreoretinopathy $(\mathrm{PVR})^{(1-5)}$. Silicone oil (SO) or perfluoropropane gas $\left(\mathrm{C}_{3} \mathrm{~F}_{8}\right)$ are recommended for retina tamponade after $\mathrm{PPV}^{(4-5)}$.

The anatomic success rate of PPV with scleral buckle, SO tamponade, and lensectomy has reached $70-90 \%$, which is considered to be acceptable ${ }^{(1,6-21)}$. However, useful visual acuity (VA) is not always achieved after this difficult and delicate surgery. In addition, several complications such as strabismus, induction of astigmatism, and change of axial length can result from scleral buckle ${ }^{(9-10)}$.

Some authours hypothesized that the complete removal of all proliferative membranes and vitreous, and the repair of all retinal breaks will lead to successful treatment of PVR without scleral buckle ${ }^{(11)}$.

There is controversy about the use of scleral buckling in PPV for 
rhegmatogenous retinal detachment. The objective of the present study was to compare pars plana vitrectomy (PPV) with and without scleral buckling as concerns visual acuity (VA) and complications such as anterior segment abnormalities, high intraocular pressure and retinal reattachment.

\section{METHODS}

Fifty-one patients with rhegmatogenous retinal detachment with PVR at different stages were submitted to vitreoretinal surgery, twenty-three patients $(45.09 \%)$ with scleral buckle (group I) and twenty-eight patients (54.90\%) without scleral buckle (group II), during a period of 2 years, with the below described vitrectomy technique.

Surgery was performed under peribulbar anesthesia by a single surgeon (R.C.S). Standard Three-port Pars Plana Vitrectomy was performed using the Accurus vitrectomy apparatus (Alcon, Fort Worth, Texas, USA) with the sclerotomies placed $4.0 \mathrm{~mm}$ (phakic eyes) or $3.5 \mathrm{~mm}$ (aphakic and pseudophakic eyes) posterior to the limbus.

Limited core vitrectomy and removal of the vitreous close to the sclerotomy used for the insertion of the vitreous cutter were initially performed. In phakic eyes, in order to avoid direct trauma of the lens caused by the vitrectomy instruments, vitrectomy at the vitreous base from the 6- to 12-o'clock position was performed with the vitreous cutter held by the right hand, and that from the 12- to 6-o'clock position was performed with the left hand ${ }^{(12)}$.

Initially, the central vitreous was removed (core vitrectomy), with later peeling of dense epiretinal membranes. Vitreous shaving was performed with scleral indentation by an assistant using a muscle hook. Next, the remaining traction points were identified, including those of hard removal, i.e., star folds with intraretinal fibrosis. At those sites, instead of removing membranes with the use of forceps, a puncture retinotomy was performed using endodiathermy. After relaxing the traction areas, subretinal fluid was aspirated with a long extensible silicone-tipped cannula, taking advantage of the created retinotomy. After this procedure, we checked whether the entire retina was attached and, if this was not the case, additional retinotomies were made to release the traction, and a new aspiration of subretinal fluid was performed.

Breaks were treated with transcleral cryoretinopexy under microscopic visualization and endoillumination or with argon laser endophotocoagulation. Treatment also involved retinal degenerative areas and precursors of retinal breaks (i.e., lattice degeneration). Cryotherapy was used for anterior breaks to avoid lens trauma from the laser probe, and photocoagulation was used for equatorial and retroequatorial breaks and along the entire edge of the puncture retinotomies. At the end of the procedure 5000 centistoke silicone oil was instilled into all eyes. All patients received a complete ophthalmologic examination including best-corrected VA, slit-lamp biomicroscopy, indirect ophthalmoscopy, and fundus color photography be- fore and after the surgery. All cases were carefully followed for development of possible complications and maintenance of retinal stability.

The best-corrected VA at the last follow-up examination was used for the analysis. The characteristics of all patients are shown in table 1.

\section{Statistical analysis}

In the comparison regarding reattachment rate, cataract formation and glaucoma, the Fisher exact test was used for statistical analysis. For visual acuity comparison, the KruskalWallis test was used. All tests were applied using 95\% confidence interval $(\mathrm{p}<0.05)$.

\section{RESULTS}

The anatomical success and postoperative complications were similar in both groups (Table 1). Retinal reattachment was achieved in 20 of 23 eyes (87\%) in group 1 and in 24 of 28 eyes $(85.7 \%)$ in group 2 after the initial surgery $(\mathrm{p}=1.000)$. Elevated intraocular pressure was noted in 2 eyes $(8.7 \%)$ of group 1 and 1 eye $(3.6 \%)$ of group $2(\mathrm{p}=0.583)$ (Figure 1). Corneal abnormalities were seen in 3 eyes (13\%) of group 1 and 2 eyes $(7.19 \%)$ of group $2(\mathrm{p}=0.647)$. The visual acuity improved from a preoperative median of 20/200 to a median of 20/100 in group 1 and from 20/400 to 20/100 in group 2; the difference between the two groups was statistically significant $(\mathrm{p}<0.05)$ (Table 1).

Anterior segment abnormalities included persistent corneal edema and cataract. Persistent corneal edema was observed in 3 eyes (13\%) of group 1 and 2 eyes (7.19\%) of group 2. There was no significant difference between both groups $(p=0.647)$ (Figure 2). Cataract occurred in $2(8.7 \%)$ eyes from group I and $6(21.4 \%)$ eyes from group II patients, with no significant difference between them $(\mathrm{p}=0.269)$ (Figure 3 ).

Retinal reattachment was achieved in 20 of 23 eyes (87\%) of group 1 and in 24 of 28 eyes (85.7\%) of group 2 after the initial surgery. The reattachment rates were similar in both groups ( $\mathrm{p}=1.000$ ) (Figure 4).

No strabismus was found in patients of both groups.

\section{DISCUSSION}

A variety of options is available for retinal detachment repair, including pneumatic retinopexy, scleral bucking and vitrectomy alone or in combination with a scleral buckle.

While scleral buckle surgery is the traditional method of retinal detachment repair ${ }^{(1)}$, the use of vitrectomy surgery is on the rise. Potential disadvantages of vitrectomy with scleral buckle include an acute change in refractive error ${ }^{(10)}$, increased swelling and discomfort during the early postoperative period, and, uncommonly, strabismus or acute or delayed infection related to the use of a foreign-body support element. 


\begin{tabular}{|c|c|c|c|c|c|c|c|}
\hline \multicolumn{8}{|c|}{ Table 1. Data of all patients } \\
\hline Patients & $\begin{array}{l}\text { SB } \\
(+/-)\end{array}$ & $\begin{array}{c}\text { Re-detachment } \\
(+/-)\end{array}$ & $\begin{array}{c}\text { Preoperative } \\
\text { VA }\end{array}$ & $\begin{array}{c}\text { Postoperative } \\
\text { VA }\end{array}$ & $\begin{array}{l}\text { High } \\
\text { IOP }\end{array}$ & $\begin{array}{c}\text { Corneal } \\
\text { abnormalities }\end{array}$ & $\begin{array}{l}\text { Follow-up } \\
\text { (months) }\end{array}$ \\
\hline 1 & - & - & CF $1 \mathrm{~m}$ & $20 / 40$ & - & - & 8 \\
\hline 2 & + & + & MM & CF $1 \mathrm{~m}$ & - & - & 7 \\
\hline 3 & - & + & $\mathrm{CF} 60 \mathrm{~cm}$ & $\mathrm{CF} 1 \mathrm{~m}$ & - & - & 9 \\
\hline 4 & - & - & CF $1 \mathrm{~m}$ & $20 / 80(-1)$ & - & - & 12 \\
\hline 5 & - & - & $20 / 25$ & $20 / 60$ & - & + & 14 \\
\hline 6 & + & - & $\mathrm{MM}$ & CF $2 \mathrm{~m}$ & + & - & 8 \\
\hline 7 & - & + & CF $60 \mathrm{~cm}$ & CF $50 \mathrm{~cm}$ & - & - & 9 \\
\hline 8 & + & - & CF $30 \mathrm{~cm}$ & $20 / 200$ & - & - & 16 \\
\hline 9 & + & - & $\mathrm{CF} 30 \mathrm{~cm}$ & $\mathrm{CF} 15 \mathrm{~cm}$ & + & + & 10 \\
\hline 10 & + & + & $20 / 200$ & MM & - & + & 6 \\
\hline 11 & + & - & $20 / 200$ & $20 / 400$ & - & + & 6 \\
\hline 12 & - & - & $\mathrm{HM}$ & $20 / 200$ & - & - & 9 \\
\hline 13 & + & - & $20 / 100$ & $20 / 60$ & - & - & 13 \\
\hline 14 & - & - & $\mathrm{HM}$ & $20 / 100$ & - & - & 14 \\
\hline 15 & + & - & CF $10 \mathrm{~cm}$ & CF $2 \mathrm{~m}$ & - & - & 10 \\
\hline 16 & - & - & $20 / 200$ & $20 / 30$ & - & - & 6 \\
\hline 17 & + & + & $20 / 20$ & CF $3 \mathrm{~m}$ & - & - & 8 \\
\hline 18 & + & - & $20 / 200$ & CF $2 \mathrm{~m}$ & - & - & 12 \\
\hline 19 & + & - & $20 / 40$ & $20 / 20$ & - & - & 18 \\
\hline 20 & + & - & $20 / 30$ & $20 / 25$ & - & - & 15 \\
\hline 21 & - & - & $\mathrm{HM}$ & CF $30 \mathrm{~cm}$ & - & - & 7 \\
\hline 22 & - & - & LP & $20 / 200$ & - & - & 11 \\
\hline 23 & - & - & CF $2 \mathrm{~m}$ & $20 / 60$ & - & - & 12 \\
\hline 24 & - & - & $20 / 60$ & $20 / 40$ & - & - & 7 \\
\hline 25 & - & - & $\mathrm{CD} 2 \mathrm{~m}$ & $20 / 400$ & - & - & 9 \\
\hline 26 & + & - & $\mathrm{HM}$ & CF $1 \mathrm{~m}$ & - & - & 6 \\
\hline 27 & - & - & $\mathrm{HM}$ & $20 / 60$ & - & - & 7 \\
\hline 28 & + & - & $\mathrm{HM}$ & $20 / 60$ & - & - & 13 \\
\hline 29 & + & - & $\mathrm{HM}$ & $20 / 80$ & - & - & 8 \\
\hline 30 & + & - & CF $60 \mathrm{~cm}$ & $20 / 200$ & - & - & 10 \\
\hline 31 & + & - & $20 / 40$ & $20 / 200$ & - & - & 11 \\
\hline 32 & - & - & $\mathrm{HM}$ & CD $20 \mathrm{~cm}$ & - & - & 6 \\
\hline 33 & + & - & $\mathrm{HM}$ & $20 / 40$ & - & - & 9 \\
\hline 34 & - & + & $\mathrm{HM}$ & $\mathrm{HM}$ & - & - & 16 \\
\hline 35 & - & + & $\mathrm{CF} 1,5 \mathrm{~m}$ & $\mathrm{HM}$ & + & + & 9 \\
\hline 36 & + & - & $\mathrm{HM}$ & $20 / 80$ & - & - & 10 \\
\hline 37 & - & - & $\mathrm{HM}$ & $20 / 200$ & - & - & 8 \\
\hline 38 & - & - & $\mathrm{HM}$ & $\mathrm{CD} 1 \mathrm{~m}$ & - & - & 9 \\
\hline 39 & - & - & $\mathrm{HM}$ & $20 / 400$ & - & - & 14 \\
\hline 40 & - & - & CF $15 \mathrm{~cm}$ & $20 / 100$ & - & - & 18 \\
\hline 41 & + & - & $20 / 100$ & $20 / 60$ & - & - & 6 \\
\hline 42 & - & - & CF $50 \mathrm{~cm}$ & CF $3 \mathrm{~m}$ & - & - & 6 \\
\hline 43 & - & - & $20 / 30$ & $20 / 100$ & - & - & 8 \\
\hline 44 & + & - & $20 / 40$ & $20 / 60$ & - & - & 9 \\
\hline 45 & - & - & $20 / 200$ & $20 / 30$ & - & - & 13 \\
\hline 46 & - & - & CF $10 \mathrm{~cm}$ & $20 / 100$ & - & - & 15 \\
\hline 47 & + & - & $\mathrm{CF} 10 \mathrm{~cm}$ & $20 / 100$ & - & - & 6 \\
\hline 48 & + & - & $\mathrm{HM}$ & $20 / 200$ & - & - & 9 \\
\hline 49 & - & - & $20 / 80$ & $20 / 200$ & - & - & 11 \\
\hline 50 & - & - & CF $1 \mathrm{~m}$ & $20 / 200$ & - & - & 13 \\
\hline 51 & - & - & $20 / 400$ & $20 / 80$ & - & - & 8 \\
\hline
\end{tabular}

Potential advantages of vitrectomy without scleral buckling include: minimal trauma to the eye, reduced pain and postope- rative swelling; minimal acute change in refractive error; reduction in floaters; and improved identification of breaks and 


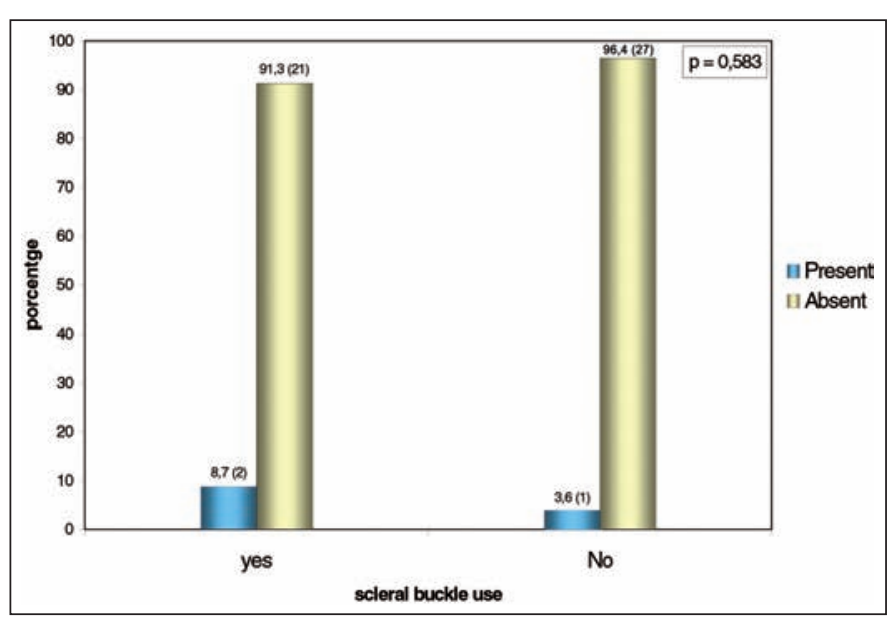

Figure 1 - Comparison of incidence of glaucoma between group with scleral buckle (yes) and group without scleral buckle (no) ( $p=$ Fisher test)

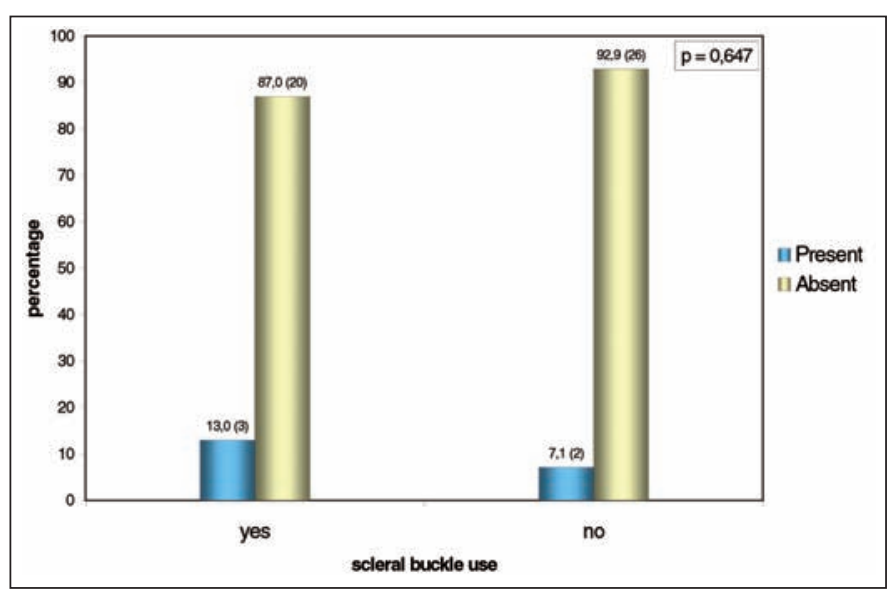

Figure 2 - Comparison of incidence of corneal abnormalities between group with scleral buckle (yes) and group without scleral buckle (no) ( $p=$ Fisher test)

reattachment during surgery, even when individual breaks cannot be located.

Some authors ${ }^{(11)}$ demonstrated that vitrectomy with vitreous shaving without scleral buckling achieved approximately the same rate of anatomic success as vitrectomy with SB in eyes with PVR and that encircling SB is not needed for the reattachment of a retina with PVR as long as all of the peripheral vitreous is removed and all retinal breaks are repaired.

Another article $^{(22)}$ reported that primary vitrectomy in combination with scleral buckling has led to a marked decrease of primary failure rate and improvement of functional results in retinal detachment surgery.

We observed in our study that the anatomical success and postoperative complications were similar in both groups (vitrectomy with and without buckle). Retinal reattachment was achieved in 20 of 23 eyes ( $87 \%$ ) of group with scleral buckle and in 24 of 28 eyes $(85.7 \%)$ of group without scleral buckle after the initial surgery $(\mathrm{p}=1.000)$. Elevated intraocular pressu-

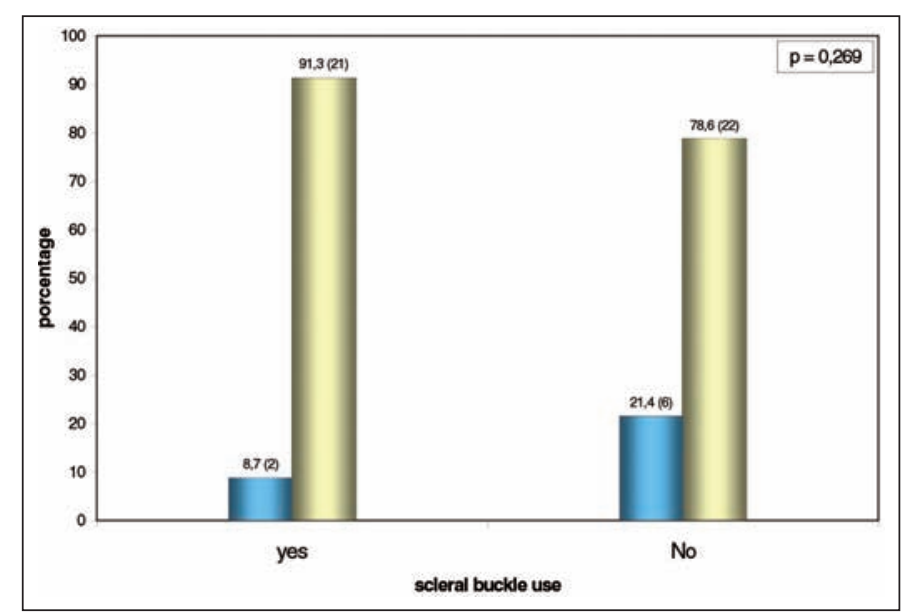

Figure 3 - Comparison of incidence of cataract between group with scleral buckle (yes) and group without scleral buckle (no) ( $p=$ Fisher test)

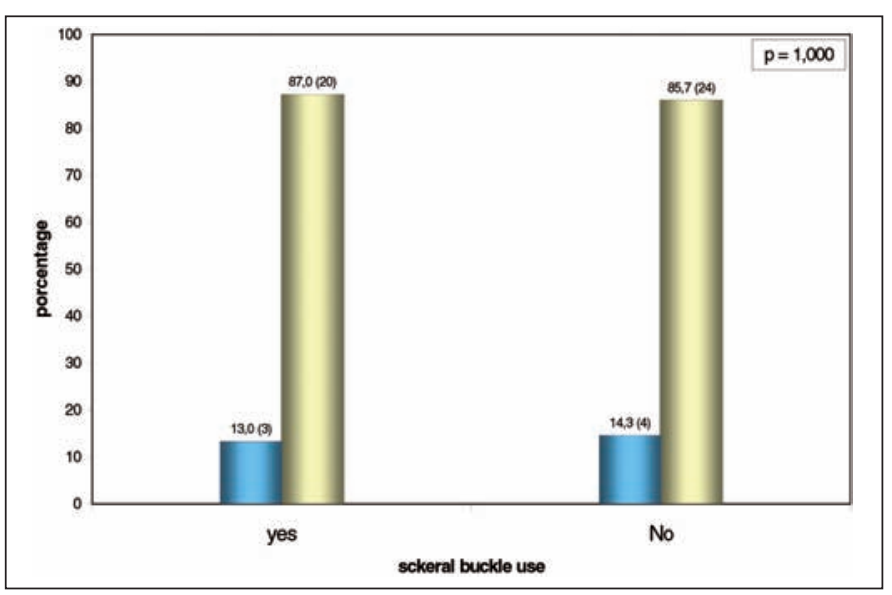

Figure 4 - Comparison of incidence of retinal reattachment between group with scleral buckle (yes) and group without scleral buckle (no) ( $p=$ Fisher test)

re was noted in 2 eyes ( $8.7 \%)$ of the group with scleral buckle and 1 eye (3.6\%) of the group without scleral buckle ( $\mathrm{p}=0.583)$. Corneal abnormalities were seen in 3 eyes (13\%) of the group with scleral buckle and 2 eyes $(7.19 \%)$ of the group without scleral buckle $(\mathrm{p}=0.647)$.

We obtained good postoperative visual recovery in the group without buckle from a preoperative median of 20/400 to a median of $20 / 100(p<0.05)$. These results were considered to be due to the reduction of the complications associated with scleral buckle mentioned previously and due to the good anatomic success rate.

\section{CONCLUSION}

In conclusion, both surgical procedures (vitrectomy with and without buckle) can achieve favorable and comparable anatomic outcomes in the majority of patients in the treatment of rhegmatogenous retinal detachment (RD). Intra- and posto- 
perative complications are similar in the two procedures. Visual acuity improved significantly in the group with vitrectomy without scleral buckle which was found to be effective to repair the primary retinal detachment.

\section{RESUMO}

Objetivos: Comparar os resultados cirúrgicos da vitrectomia com e sem "buckle" escleral para descolamento da retina regmatogênico (DR). Métodos: Cinqüenta e um pacientes com descolamento da retina regmatogênico com proliferação vitreorretiniana (PVR) em diferentes estádios foram submetidos a vitrectomia pars plana como cirurgia primária; 23 pacientes $(45,09 \%)$ com buckle escleral (grupo 1) e 28 pacientes $(54,90 \%)$ sem "buckle" escleral (grupo 2). Acuidade visual, complicações do segmento anterior, pressão intra-ocular, estrabismo e razão do redescolamento da retina foram avaliados em ambos os grupos. Resultados: O sucesso anatômico e complicações pós-operatórias foram semelhantes em ambos os grupos. A reaplicação da retina foi obtida em 20 dos 23 olhos (87\%) no grupo 1 e em 24 dos 28 olhos $(85,7 \%)$ no grupo 2 após a cirurgia inicial $(\mathrm{p}=1,000)$. Aumento da pressão intra-ocular foi notada em 2 olhos $(8,7 \%)$ no grupo 1 e em 1 olho $(3,6 \%)$ no grupo 2 ( $\mathrm{p}=0,583)$. Anormalidades na córnea foram vistas em 3 olhos (13\%) no grupo 1 e em 2 olhos $(7,19 \%)$ no grupo $2(p=0,647)$. A acuidade visual melhorou de uma média pré-operatória de 20/200 para uma média de 20/100 no grupo 1 e de 20/400 para 20/100 no grupo 2, com diferença estatisticamente significativa entre os grupos $(\mathrm{p}<0,05)$. O período médio de seguimento foi de 10 meses, variando entre 6 e 18 meses. Conclusões: Ambos procedimentos cirúrgicos tiveram razão semelhante de reaplicação da retina. Complicações intra- e pós-operatória foram semelhantes em ambos os procedimentos. A acuidade visual melhorou significativamente no grupo 2 (vitrectomia sem "buckle" escleral).

Descritores: Descolamento retiniano; Recurvamento da esclera; Vitrectomia; Acuidade visual; Estudo comparativo

\section{REFERENCES}

1. Hanneken AM, Michels RG. Vitrectomy and scleral buckling methods for proliferative vitreoretinopathy. Ophthalmology. 1988;95(7):865-9.

2. Lewis H, Aaberg TM, Abrams GW. Causes of failure after initial vitreoretinal surgery for severe proliferative vitreoretinopathy. Am J Ophthalmol. 1991;111 (1):8-14.
3. Lewis H, Aaberg TM, Abrams GW. Causes of failure after repeat vitreoretinal surgery for recurrent proliferative vitreoretinopathy. Am J Ophthalmol. 1991; 111(1):8-14.

4. Silicone Study Group. Silicone study group report 1 . Vitrectomy with silicone oil or sulfur hexafluoride gas in eyes with severe proliferative vitreoretinopathy: results of a randomized clinical trial. Arch Ophthalmol. 1992;110(6):770-9. Comment in: Arch Ophthalmol. 1992;110(6):768-9. Arch Ophthalmol. 1993; 111(4):428; author reply 429.

5. Silicone Study Group. Silicone study group report 2. Vitrectomy with silicone oil or perfluoropropane gas in eyes with severe proliferative vitreoretinopathy: results of a randomized clinical trial. Arch Ophthalmol. 1992;110(6):780-92. Comment in: Arch Ophthalmol. 1992;110(6):768-9. Arch Ophthalmol. 1993; 111(4):428; author reply 429. Arch Ophthalmol. 1994;112(6):728-9.

6. Coll GE, Chang S, Sun J, Wieland MR, Berrocal MH. Perfluorocarbon liquid in the management of retinal detachment with proliferative vitreoretinopathy. Ophthalmology. 1995;102(4):630-8; discussion 638-9.

7. Fisher YL, Shakin JL, Slakter JS, Sorenson JA, Shafer DM. Perfluoropropane gas, modified panretinal photocoagulation, and vitrectomy in the management of severe proliferative vitreoretinopathy. Arch Ophthalmol. 1988;106(9):1255-60.

8. Cox MS, Trese MT, Murphy PL. Silicone oil for advanced proliferative vitreoretinopathy. Am J Ophthalmol. 1986;93(5):646-50.

9. Smiddy WE, Loupe D, Michels RG, Enger C, Glaser BM, deBustros S. Extraocular muscle imbalance after scleral buckling surgery. Ophthalmology. 1989;96 (10):1485-9; discussion 1489-90.

10. Rubin ML. The induction of refractive errors by retinal detachment surgery. Trans Am Ophthalmol Soc. 1975;73:452-90.

11. Oyagi T, Emi K. Vitrectomy without scleral buckling for proliferative vitreoretinopathy. Retina. 2004;24(2):215-8.

12. Brazitikos PD. The expanding role of primary pars plana vitrectomy in the treatment of rhegmatogenous non-complicated retinal detachment. Semin Ophthalmol. 2000;15(2):65-77.

13. Leaver PK, Grey RHB, Garner A. Silicone oil injection in the treatment of massive preretinal retraction. II. Late complications in 93 eyes. Br J Ophthalmol. 1979;63(5):361-7.

14. Lewis H, Burke JM, Abrams GW, Aaberg TM. Persilicone proliferation after vitrectomy for proliferative vitreoretinopathy. Ophthalmology. 1988;95(5):583-91.

15. Abrams GW, Azen SP, Barr CC, Lai MY, Hutton WL, Trese MT, et al. The incidence of corneal abnormalities in the Silicone Study. Silicone Study Report 7. Arch Ophthalmol. 1995;113(6):764-9.

16. Cox MS, Azen SP, Barr CC, Linton KL, Diddie KR, Lai MY, et al. Macular pucker after successful surgery for proliferative vitreoretinopathy. Silicone Study Report 8. Ophthalmology. 1995;102(12):1884-91.

17. Barr CC, Lai MY, Lean JS, Linton KL, Trese M, Abrams G, et al. Postoperative intraocular pressure abnormalities in the Silicone Study. Silicone Study Report 4. Ophthalmology. 1993;100(11):1629-35.

18. Andenmatten R, Gonvers M. Sophisticated vitreous surgery in patients with a healthy fellow eye. Graefes Arch Clin Exp Ophthalmol. 1993;231(9):495-9.

19. Lewis H, Aaberg TM. Anterior proliferative vitreoretinopathy. Am J Ophthalmol. 1988;105(3):277-84.

20. Machemer R, Aaberg TM, Freeman HM, Irvine AR, Leam JS, Michels M. An updated classification of retinal detachment with proliferative vitreoretinopathy. Am J Ophthalmol. 1991;112(2):159-65.

21. Salicone A, Smiddy WE, Venkatraman A, Feuer W. Management of retinal detachment when no break is found. Ophthalmology. 2006;113(3):398-403.

22. Martinez-Castillo V, Verdugo A, Boixadera A, Garcia-Arumi J, Corcostegui B. Management of inferior breaks in pseudophakic rhegmatogenous retinal detachment with pars plana vitrectomy and air. Arch Ophthalmol. 2005;123(8): 1078-81.

\section{Ao enviar um artigo para publicação,} leia ATENTAMENTE as instruçóes para autores, constante no final de cada fascículo. 